\title{
Morphological Study of Larval Development and the Transition to Juvenile Stage in Thin-Lipped Mullet, Liza Ramada
}

\author{
Original Mostafa A. Mousa ${ }^{1}$, Noha A. Khalil ${ }^{1}$ and Nawal M. El-Gohary ${ }^{2}$ \\ Article \\ ${ }^{1}$ Fish Reproduction Laboratory, National Institute of Oceanography and Fisheries, Alexandria, \\ Egypt, \\ ${ }^{2}$ Faculty of Science, Gazan University, KSA
}

\begin{abstract}
Introduction: The detailed description of larval and juvenile stages of L. ramada is so far lacking.

Aim of the Work: The present study aimed to describe larval development and the morphological transition to the juvenile stage in L. ramada after artificial spawning.

Material and Methods: In this study, we described early development of Liza ramada over the early rearing period of 63 days post-hatching.

Results: The newly hatched larvae have closed mouth and anus. At seven days post-hatching, the larvae have opened mouth and both yolk sac and oil globules disappeared. At 14 days, larvae have a distinct fins and increased skin pigmentation. At 21 days post-hatching, the larvae have variable coloration with more density. At 28 days post-hatching, the body depth of larvae increased and the stomach contains some food indicating the larval ability to digest external food. In 35 days-old larvae, the eyes become fully pigmented. At 42 days post-hatching, the larvae have high density of pigmentation all over the body and transparent caudal fin with rays. At 49 days post-hatching, the body of juvenile is distinctly elongated and laterally compressed with obvious scales. By 56 days post-hatching, the fish is covered with scales and well-developed rays. At 63 days post-hatching, the body becomes large and completely covered with scales and high density of pigmentation. The larvae begin transformation to juvenile stage at 42 days post-hatching and then finished the transformation at 63 days post-hatching. Importantly, the juvenile stage of L. ramada can be handled safely at 63 days post-hatching.
\end{abstract}

Conclusion: The juvenile's production of L. ramada requires a period of 63 .

Received: 20 January 2020, Accepted: 12 February 2020

Key Words: Early development, liza ramada larvae, thin-lipped mullet.

Corresponding Author: Mostafa A. Mousa, PhD, National Institute of Oceanography and Fisheries, QayetBay, 21411, Anfoushy,Alexandria, Egypt, Tel.: +20 1001082930,E-mail: mostafa_mousa2002@yahoo.com

ISSN: 1110-0559, Vol. 43, No.4

\section{INTRODUCTION}

The thin-lipped grey mullet, Liza ramada (Risso) constitutes a very important target for farming in the sea, brackish and fresh water. The culture of mullet is closely dependent on the availability of their fry. The present fry collection from nature does not satisfy the increasing demand for the juveniles of Liza ramada. Therefore, it is necessary to develop and establish practical techniques for artificial propagation of mullet in order to substitute the fry collection from wild stocks ${ }^{[1]}$. In addition, the success of larval rearing has been a bottleneck in the culture of many marine finfish species. The maintenance of larval survival and growth are limited by the availability of food, especially at the early larval stage and transition period from endogenous to exogenous nutritional sources ${ }^{[2-4]}$. The transition from endogenous to exogenous feeding is one of the most crucial time $^{[4-6]}$ and, during this weaning period, mass mortalities have been routinely observed ${ }^{[7,8]}$.

Larval development of Mugilidae species has been investigated by a few studies with specific regards to early days of larvae hatching. Indeed, the larvae of M. curema exhibit a size of $2.5 \mathrm{~mm}$ at only $32 \mathrm{~h}$ after hatching ${ }^{[9]}$. Also, the early larval development of the striped mullet, M. cephalus and transformation to the juvenile size in inshore areas was described and illustrated ${ }^{[10]}$.

Then, only seven post larvae and one juvenile of the golden mullet, L. auratusas well as two post larvae of the thick-lipped mullet Creni mugil labrosus ranging from 6.0 to $27 \mathrm{~mm}$ was described ${ }^{[11]}$. In addition, the early development and morphological transition from the larval to the juvenile stage of laboratory-reared redlip mullet, Liza haematocheila and Liza affinis was demonstrated ${ }^{[12]}$. In parallel, several studies investigated the early development, growth, and morphological changes of the larvae in other fish species such as Atlantic cod, Gadus morhua ${ }^{[13]}$, the green wrasse, Labrus viridis ${ }^{[14]}$, yellowtail kingfish Seriola lalandi ${ }^{[15]}$, silver therapon Leiopothera ponplumbeus ${ }^{[16]}$, Red Spotted Grouper, Epinephelus akaara ${ }^{[17]}$, Japanese flounder, Paralichthys olivaceus ${ }^{[18-20]}$ and Hilsa shad, Tenualo sailisha ${ }^{[4]}$. 
Despite the successes in artificial propagation of the mullet, by artificial spawning ${ }^{[1,21,22]}$, there is still a need to refine further techniques of larval rearing particularly for practical and commercial applications. In our previous limited study ${ }^{[1]}$, we described the newly hatched larvae of thinlipped mullet, Liza ramada only until 5 days post-hatching. However, information on the early larval development and the morphological transition from the larvae to the juvenile stage of thin-lipped mullet, Liza ramada obtaining from induced spawning in captivity is lacking. Therefore, the present study extends our previous investigation and aimed to describe in details, early larval development and the morphological transition from the larvae to the juvenile stage of thin-lipped mullet, Liza ramada over the early rearing period of 63 days post-hatching.

\section{MATERIAL AND METHODS}

\subsection{Experimental design of rearing Liza ramada larvae}

The present study was performed at El-Matareyya Research Station, National Institute of Oceanography and Fisheries. The experimental work was carried out in the fish hatchery during the spawning season (during November and December) of the mullet fish, Liza ramada.

After induced spawning with hormonal and environmental stimulation ${ }^{[22]}$ and obtaining of Liza ramada larvae, the newly hatched larvae were stocked at a density of 20 individuals (ind) L-1 in glass aquaria (three aquaria; $50 \mathrm{~L}$ capacity each). The aquaria contain sterilized sea-water (32\%o salinity) at a temperature of $21 \pm 2^{\circ} \mathrm{C}$; under different feeding regimes ${ }^{[23]}$ for three periods. These periods include green water (Nannochloropsis oculata, $2.5 \times 105$ cells $/ \mathrm{ml}$ ) for 7 days, green water conditions with rotifers $\left(8-10 \mathrm{ml}^{-1}\right)$ for 28 days and Artemia enriched with Nannochloropsis oculata $\left(4-6 \mathrm{ml}^{-1}\right)$ for 28 days.

The aquaria were covered with black plastic sheeting to maintain dark conditions. Rearing of larvae was performed in static aerated water up to 3 days post hatching (dph). The water was partially replaced (5-6\% daily) from 4 to $12 \mathrm{dph}$. Out-flowing water was strained through a $150 \mu \mathrm{m}$ mesh. The water exchange rate was increased gradually with the age of the larvae (up to $25 \%$ ). Debris and dead larvae were siphoned out each day before changing the water. The experiment was conducted for 63 days.

\subsection{Early development of Liza ramada larvae}

Samples of larvae were collected immediately after hatching and at 9 weekly intervals (10 stages) for growth measurements and developmental progress. Growth was monitored by measuring the total length (TL) of larvae (initial $\mathrm{n}=25$ ) at approximately weekly intervals. Measurement of the newly hatched larvae and larval stages were performed under a stereo microscope using an eyepiece micrometer calibrated with a standard decimal millimeter (Model: SMZ-2 Optika Italy). Digital images were taken to measure morphological and developmental progress.

\section{RESULTS}

The development of $\mathrm{L}$. ramada larvae at ten stages starting from $0,7,14,21,28,35,42,49$, 56 till 63 days post-hatching (dph) were described (see Figures $1-10$ and Table 1).

\subsection{Larvae at 0 day post-hatching}

At zero-day post-hatching (dph), the total length and the body weight of L. ramada larvae containing 25 somites ranged from 3.4 to $3.6 \mathrm{~mm}$ and 0.9 to $1.1 \mathrm{mg}$ (Table 1), respectively. After few hours post-hatching, the body and the gut became straight. The larvae exhibit more pronounced pigmentation all over the body, visible membranous fins and closed mouth as well as anus. The larvae have a large ovalshaped yolk sac with an oil droplet at its posterior end with no pigmentation over the yolk (Figure 1)

\subsection{Larvae at 7 days post-hatching}

At seven dph, the total length and the body weight of L. ramada larvae ranged from 4 to $6 \mathrm{~mm}$ and 2.9 to $3.1 \mathrm{mg}$ (Table 1), respectively. The body is distinctly elongated and laterally compressed. The mouth became open and supported with well-developed upper and lower jaws, which able to take of exogenous food. In parallel, the Yolk sac and oil globules disappeared but the fins distinctly appeared. The eyes are relatively large. The pigmentation of larvae extends from the head along the trunk to the tail. In addition, the larvae provided with transparency caudal fin (Figure 2).

\subsection{Larvae at 14 days post-hatching}

At $14 \mathrm{dph}$, the total length and the body weight of $\mathrm{L}$. ramada larvae ranged from 5.9 to $6.1 \mathrm{~mm}$ and 4.8 to 5.1 mg (Table 1), respectively. The body is distinctly elongated and laterally compressed with well- developed lateral line. Eyes are large. The opened gill is relatively large. The body pigmentation increases in the density gradually from the head to trunk and reached to the high density on the posterior region. The caudal fin is more transparent (Figure 3).

\subsection{Larvae at 21 days post-hatching}

At $21 \mathrm{dph}$, the total length and body weight of L. ramada larvae ranged from 7 to $9 \mathrm{~mm}$ and 5.5 to $6.5 \mathrm{mg}$ (Table 1), respectively. The larvae exhibit variable coloration and interrupted lateral line. The body pigmentation became more dens from the head to trunk and reached to high density on the posterior region (Figure 4).

\subsection{Larvae at 28 days post-hatching}

At $28 \mathrm{dph}$, the total length and body weight of L. ramada larvae ranged from 8.5-9.5 $\mathrm{mm}$ and 6.5-7.5 $\mathrm{mg}$ (Table 1), respectively. The body depth increases concomitant with the increase of abdomen. The mouth larva became relatively large and protrusible with movable upper and lower jaws. The stomach contains some of food indicating the larval ability to digest external food. The larva has high density of pigmentation around eye and on the caudal peduncle. The 
caudal fin became more transparent than the previous stage (Figure 5).

\subsection{Larvae at 35 days post-hatching}

At $35 \mathrm{dph}$, the total length and body weight of L. ramada larvae ranged from $11-13 \mathrm{~mm}$ and $11-13 \mathrm{mg}$ (Table 1), respectively. The opened mouth is large and supported with movable jaws which able to engulf plankton. The larva has high density of pigmentation around eye and on the caudal peduncle. (Figure 6).

\subsection{Larvae at 42 days post-hatching}

At $42 \mathrm{dph}$, the total length and body weight of L. ramada larvae ranged from 14-18 mm and 11-16 mg (Table 1), respectively. The opened mouth is large in size and movable jaws in order to engulf plankton. The larvae body surface covered with high density of pigmentation. The caudal fin supported with rays is more transparent (Figure 7).

\subsection{Juvenile at 49 days post-hatching}

At $49 \mathrm{dph}$, the total length and body weight of L. ramada juvenile ranged from 13-19 $\mathrm{mm}$ and 17-22 mg (Table1), respectively. The full-grown young fish has variable coloration and interrupted lateral line. The juvenile body is distinctly elongated, laterally compressed and supported with origin scales. The juvenile body surface covered with a high density of pigmentation. In parallel, the caudal fin is more transparent and supported with rays (Figure 8).

\subsection{Juvenile at 56 days post-hatching}

At $56 \mathrm{dph}$, the total length and body weight of $\mathrm{L}$. ramada juvenile ranged from $15.5-19 \mathrm{~mm}$ and $34-36 \mathrm{mg}$ (Table 1), respectively. The full-grown young fish has variable coloration and laterally compressed body. In addition, the body is partially covered with minute scales. The juvenile has high density of pigmentation all over the body surface. The caudal fin is more transparent and the fin rays are well developed (Figure 9).

\subsection{Juvenile at 63 days post-hatching}

At $63 \mathrm{dph}$, the total length and body weight of L. ramada juvenile ranged from 21-24 mm and 70-74 mg (Table 1), respectively. The body became completely covered with scales. The juveniles exhibit large size, high density of pigmentation covering the body surface and well developed fin rays (Figure 10).

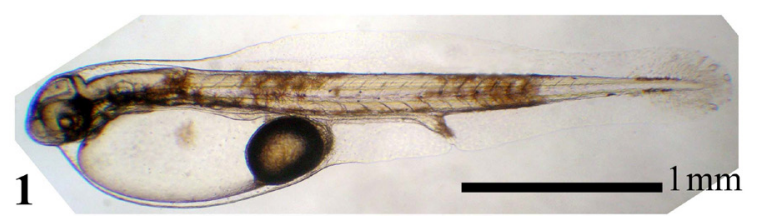

Fig. 1: Lateral view of L. ramada larvae at 0 day post-hatching. Scale bar $=1 \mathrm{~mm}$.

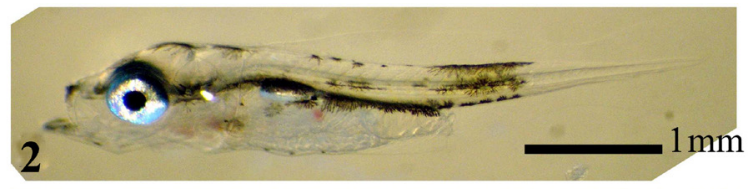

Fig. 2: Lateral view of L. ramada larvae at 7 day post-hatching. Scale bar $=1 \mathrm{~mm}$.

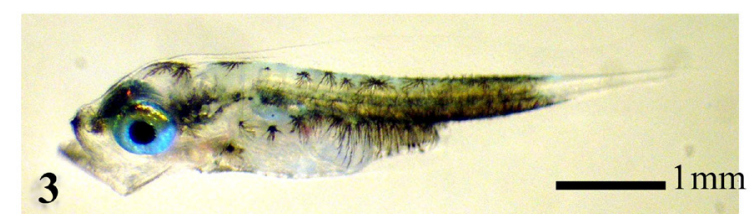

Fig. 3: Lateral view of L. ramada larvae at 14 day post-hatching. Scale bar $=1 \mathrm{~mm}$.

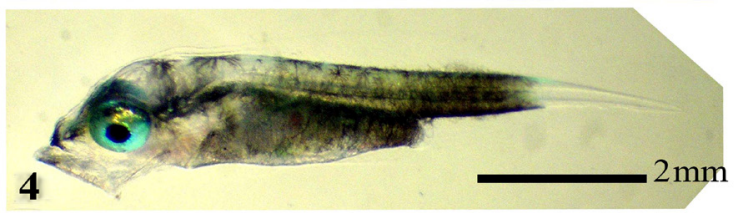

Fig. 4: Lateral view of L. ramada larvae at 21 day post-hatching. Scale bar $=2 \mathrm{~mm}$.

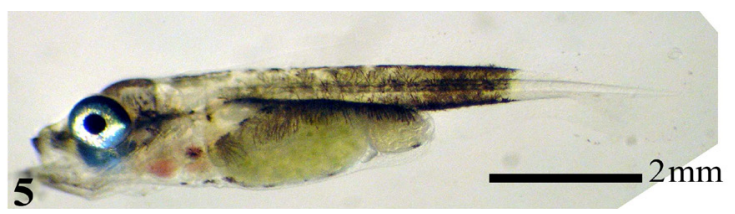

Fig. 5: Lateral view of L. ramada larvae at 28 day post-hatching. Scale bar $=2 \mathrm{~mm}$.

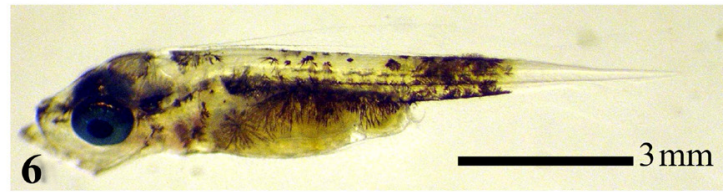

Fig. 6: Lateral view of L. ramada larvae at 35 day post-hatching. Scale bar $=3 \mathrm{~mm}$.

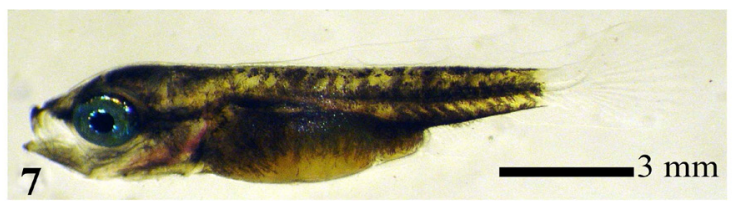

Fig. 7: Lateral view of L. ramada larvae at 42 day post-hatching. Scale bar $=3 \mathrm{~mm}$.

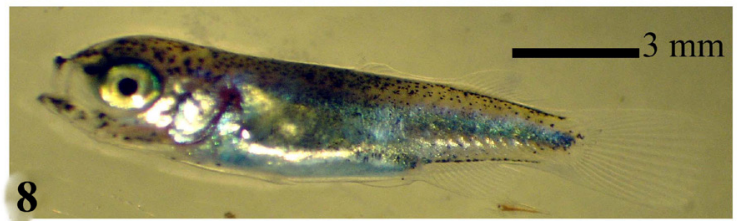

Fig. 8: Lateral view of L. ramada larvae at 49 day post-hatching. Scale bar $=3 \mathrm{~mm}$. 


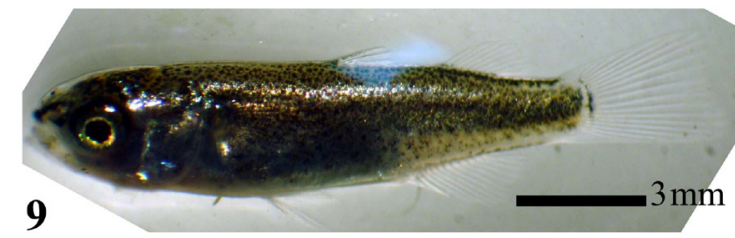

Fig. 9: Lateral view of L. ramada larvae at 56 day post-hatching. Scale bar $=3 \mathrm{~mm}$.

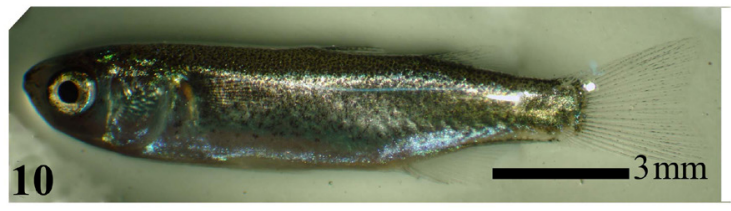

Fig. 10: Lateral view of L. ramada larvae at 63 day post-hatching. Scale bar $=3 \mathrm{~mm}$.

Table 1: The total body length (Range, mean $\pm \mathrm{SD} \mathrm{mm}$ ) and total body weight (Range, mean $\pm \mathrm{SD} \mathrm{mg}$ ) of Liza ramada larvae and juveniles, obtaining by spawning induction

\begin{tabular}{|c|c|c|c|c|c|}
\hline \multirow{2}{*}{ Developmental stage of larvae } & \multirow{2}{*}{ No of larvae } & \multicolumn{2}{|c|}{ Total body length $(\mathrm{mm})$} & \multicolumn{2}{|c|}{ Total body weight $(\mathrm{mg})$} \\
\hline & & Range & Mean \pm SD & Range & Mean \pm SD \\
\hline Larvae at 0 day & 25 & $3.4-3.6$ & $3.5 \pm 0.07$ & $0.9-1.1$ & $1 \pm 0.07$ \\
\hline Larvae at 7 days & 25 & $4-6$ & $5 \pm 0.71$ & $2.9-3.1$ & $3 \pm 0.06$ \\
\hline Larvae at 14 days & 25 & $5.9-6.1$ & $6 \pm 0.04$ & $4.8-5.1$ & $5 \pm 0.08$ \\
\hline Larvae at 21 days & 25 & $7-9$ & $8 \pm 0.45$ & $5.5-6.5$ & $6 \pm 0.22$ \\
\hline Larvae at 28 days & 25 & $8.5-9.5$ & $9 \pm 0.22$ & $6.5-7.5$ & $7 \pm 0.22$ \\
\hline Larvae at 35 days & 25 & $11-13$ & $12 \pm 0.55$ & $11-13$ & $12 \pm 0.55$ \\
\hline Larvae at 42 days & 25 & $14-18$ & $15 \pm 1.43$ & $11-16$ & $14 \pm 1.26$ \\
\hline Juveniles at 49 days & 25 & $13-19$ & $16.1 \pm 1.46$ & $17-22$ & $20 \pm 1.26$ \\
\hline Juveniles at 56 days & 25 & $15.5-19$ & $16.3 \pm 1.57$ & $34-36$ & $35 \pm 0.63$ \\
\hline Juveniles at 63 days & 25 & $21-24$ & $22 \pm 1.05$ & $70-74$ & $72 \pm 1.05$ \\
\hline
\end{tabular}

\section{DISCUSSION}

The induced spawning of L. ramada in our spawning laboratory, at El-Matareyya Research Station, National Institute of Oceanography and Fisheries, allowed us to integrate the scanty data on the development of this species. The embryonic and larval stages are very sensitive to environmental disturbances. Moreover, studies on larval development of any cultivable species are useful in directing the hatchery efforts of fish farmers to succeed in their efforts on seed production by promoting larval growth and survival rate. In the present study, we described the details of larval development of L. ramada. Our findings extend the description of embryonic and early larval development of L. ramada ${ }^{[24]}$. Their descriptions are incomplete, as far as developmental details and/or the sequence of stages during the transition from the larvae to the juvenile is lacking. Also, our study extends the limited description of embryonic and early larval development of L. ramada was illustrated ${ }^{[1]}$.

Here, the present description of larval development of L. ramada has some similarity with that of other Mugiliformes fishes ${ }^{[25-28]}$, silver sea bream; Sparus sarba ${ }^{[29]}$, longtooth grouper Epinephelus bruneus ${ }^{[30]}$ and dusky grouper Epinephelus marginatus ${ }^{[31]}$. However, the real difference is that the differences in the required time for the development of different stages; this may be due to the difference in the incubation temperature in different species. During early developmental stages, marine fish are very sensitive to environmental changes ${ }^{[19,20]}$. Egg development and hatching time are both temperature dependent. Therefore, good temperature control during incubation is crucial. The present experiments on the L. ramada propagation performed within the most desirable temperature range and mostly at the optimum level. In normal seawater $(35 \%)$, the fertilized eggs developed and hatched within $48 \mathrm{~h}$ at $20-21^{\circ} \mathrm{C}$ consistent with the previous observation ${ }^{[1]}$. In this respect, under laboratory conditions the eggs of $\mathrm{M}$. cephalus and $\mathrm{M}$. capito developed and hatched within a time of 36-44 $\mathrm{h}$ at $22-32{ }^{\circ} \mathrm{C}^{[24]}$. Also, hatching of M. cephalus eggs was evident $36-38 \mathrm{~h}$ after fertilization at $24{ }^{\circ} \mathrm{C}$, and $48-50 \mathrm{~h}$ at $22^{\circ} \mathrm{C}^{[23]}$. In addition, hatching begin at $30 \mathrm{hrs}$ and completed at 32 hrs at a temperature of $26-28^{\circ} \mathrm{C}$ and salinity of $26 \mathrm{ppt}^{[28]}$. However, development and hatching of the thick-lipped mullet (Chelon labrosus) occurs at 3 days after spawning, at a water temperatures ranging from 15.7 to $18.7^{\circ} \mathrm{C}^{[25]}$.

The present results indicated that, the newly hatched larvae of L. ramada had one oil globule situated in the posterior part of the yolk as well as opened mouth and anus on the $5^{\text {th }}$ day post-hatching. Moreover, the feeding on the exogenous nutrition began at the five days post-hatching after yolk-sac absorption. These results were in agreement with the previous studies ${ }^{[1,4,16,17,32]}$. However, feeding process began three to five days post-hatching of the newly hatched larvae of M. cephalus ${ }^{[33]}$. However, in Chelon labrosus the mouth opening occurred 6 days $8 \mathrm{~h}$ after spawning ${ }^{[25]}$.

The previous studies stated that the juvenile stage defined morphologically by the presence of fin rays and scales $^{[30]}$. In the present study, the juvenile stage of L. ramada began at day 42 post-hatching and completed at 63- day old. Also, scales were first observed in specimens $>20 \mathrm{~mm}$. This observation is consistent with that obtained in dusky 
grouper Epinephelus marginatus ${ }^{[31]}$. Scales are involved in protection and serve as a calcium deposit ${ }^{[31,34-36]}$. After 42 days, the young fish of L. ramada school together. Then, they can handle and transferred safely after 63 days. The morphological transition from the larval to the juvenile stage in redlip mullet, Liza haematocheila, occurred during the $25^{\text {th }}$ to 29th days between 12.0 and $14.0 \mathrm{~mm}$ in total length (TL) [26]. When the larvae transformed to juveniles, the third anal fin ray had not yet transformed into a spine. In thick-lipped mullet, Chelon labrosus, the juvenile stage completed at 60 days post-hatching ${ }^{[25]}$. Also, by day 51 post-hatching all the larvae of keelback mullet, Liza carinata transformed into juveniles $^{[27]}$. In red spotted grouper, Epinephelus akaara, the juveniles were completed at $55 \mathrm{~d}$ post-hatching ${ }^{[17]}$. However, in yellowtail kingfish Seriola lalandi, the juvenile stage is completed $30 \mathrm{dph}^{[15]}$.

\section{CONCLUSION}

The present results showed that juvenile's production of L. ramada require a period of 63 days. Indeed, the juvenile stage of L. ramada began at day 42 after hatching and completed at 63 days old. Importantly, the younger fish school together after 42 days and can be safely handled and transferred after 63 days.

\section{ACKNOWLEDGEMENT}

We are extremely grateful to Professor Shaaban Mousa (Klinik fur Anaesthesiologie, Charite-UniversitatsmedizinBerlin) for critical review of the manuscript.

\section{CONFLICTS OF INTEREST}

There are no conflicts of interest.

\section{REFERENCES}

1. Mousa MA. Induced spawning and embryonic development of Liza ramada reared in freshwater ponds. Animal Reproduction Science (2010) 119: 115-122.

2. Fraser JH. The ecology of the ctenophore Pleurobrachia pileus in Scottish waters. ICES J. Cons. (1970) 33: 149 - 168.

3. Cushing DH. Cambridge University Marine Ecology and Fisheries. Press, Cambridge, UK (1975).

4. Riar Md GS, Ara R, Amin SMN, Kamarudin Mohd S, Wahab Md, Raushon A, Nur- A-, Arockiaraj J, Arshad A. Mouth morphological development of Hilsa (Tenualosailisha) larvae collected from Meghna Estuary, Bangladesh. Journal of Environmental Biology (2018) 39: 877.

5. Conides AJ, Glamuzina B. Study on the early larval development and growth of red progy, Pagrus pagrus with emphasis on the mass mortalities observed during this phase. Sci. Mar. (2001) 65: 193-200.

6. Moteki M, Ishikawa T, Teraoka N, Fushimi $\mathrm{H}$. Transition from endogenous to exogenous nutritional sources in larval sea bream Pagrus major. Suisanzoshoku (2001) 49: 323-328.

7. Kamler E. Early life history of fish. An energetic approach. Chapman \& Hall, London (1992), p. 183.

8. Haniffa MA, Arockiaraj AJ, Sridhar S. Weaning diet for striped murrelChannastriatus. Fish.Technol (1999) 36:116-119.

9. Anderson WW. Early development, spawning, growth and occurrence of the silver mullet (Mugil curema) along the South Atlantic coast of the United States. Fish. Bull. Fish Wildl. Serv. U.S. (1957) 57: 397- 414.

10. Anderson WW. Larval development, growth, and spawning of striped mullet (Mugil cephalus) along the South Atlantic coast of the United States. Fish. Bull. Fish Wild. Serv. U.S. 5s (1959): 501-519.

11. Demir N. On the occurrence of grey mullet post-larvae of Plymouth. J. Mar. Biol. Assoc. U.K. (1971) 51:235-246.

12. Yoshimatsu T, Matsui S, Kitajima C. Early development of laboratory-reared keelback mullet. Nippon Suisan Gakkaishi. (1993) 59 (5): 765 - 776.

13. Avery TS, Killen SS, Hollinger TR. The relationship of embryonic development, mortality, hatching success, and larval quality to normal or abnormal early embryonic cleavage in Atlantic cod, Gadus morhua. Aquaculture (2009) 289: 265 - 273.

14. Kozul V, Glavic N, Tutman P, Bolotin J, Onofri V. The spawning, embryonic and early larval development of the green wrasse, Labrusviridis (Linnaeus, 1758) (Labridae) in controlled conditions.Animal Reproduction Science (2011) 125: 196 - 203.

15. Martínez-Montaño E, González-Alvarez K, Lazo JP, Audelo-Naranjo JM,Vélez-Medel A. Morphological development and allometric growth of yellowtail kingfish Seriola lalandi V. larvae underculture conditions. Aquaculture Research (2014) 47: 1277-1287.

16. Aya FA, Nillasca VSN, Garcia LMB,Takag Y. Embryonic and larval development of hatchery-reared silver therapon Leiopothera ponplumbeus (Perciformes: Terapontidae). Ichthyol. Res. (2016) 63: 121-131.

17. Park JY, Cho JK, Son MH, Kim KM, Han KH, Park JM. Artificial Spawning Behavior and Development of Eggs, Larvae and Juveniles of the Red Spotted Grouper, Epinephelus akaarain Korea. Dev. Reprod. (2016) 20(1): 31-40.

18. Wang Y, Guo Q, Zhao H, Liu H, Lu W. Larval development and salinity tolerance of Japanese flounder (Paralichthys olivaceus) from hatching to juvenile settlement. Aquaculture Research (2013) 46: $1878-1890$. 
19. Wang Y, Guo Q, Zhao H, Liu H, Lu W. Larval development and salinity tolerance ofJapanese flounder (Paralichthys olivaceus) from hatching to juvenile settlement. Aquaculture Research (2015) 46: 1878-1890.

20. Geng J, Belfranin C, Zander IA, Goldstein E, Mathur S, Lederer BI, Benvenuti R, Benetti Daniel D. Effect of stocking density and feeding regime on larval growth, survival, and larval development of Japanese flounder, Paralichthys olivaceus, using live feeds. J. World Aquacult. Soc. (2018) 50: 336-345.

21. Mousa MA, Khalil NA. Environmental and hormonal control of induced spawning in thinlipped grey mullet, L. ramada (Risso). Egypt. J. Histol. (2013) 36 (2): 449-458.

22. Mousa MA, Kora MF, Khalil NA. Evaluation of the effectiveness and cost of different hormones in stimulating the spawning of thin lipped grey mullet, Liza ramada. Egypt. J. Histol. (2018) 41(3): 123-132.

23. Kuo CM, Shehadeh ZH, Milisen KK. A preliminary report on the development, growth and survival of laboratory reared larvae of the grey mullet, Mugil cephalus L. J. Fish Biol. (1973) 5: 459 - 470.

24. Yashouv A, Berner-Samsonov E. Contribution to the knowledge of eggs and early larval stages of mullets (Mugilidae) along the IsraelCoast. Bamidgeh, Bull. Fish Cult.Israel. (1970) 22: 72-89.

25. Boglione C, Bertolini B, Russiello M, Cataudella S. Embryonic and larval development of the thick-lipped mullet (Chelon labrosus) under controlled reproduction conditions. Aquaculture (1992) 101: 349 - 359.

26. Yoshimatsu T, Matsui S, Kitajima C. Early development of laboratory-reared redlip mullet, Liza haematocheila. Aquaculture (1992) 105: 379 - 390.

27. Ismail WA, Al-Abdul-Elah K, Al-Yamani F. Larval development of the back keeled mullet Liza carinata.
Hydrobiologia (1998) 385: 87-105.

28. Abraham M, Shiranee P, Kishore Chandra P, Kailasam M, Charles VK. Embryonic and larval development of the striped mullet, Mugil cephalus (L). Indian J. Fish. (1999) 46 (2): 123-131.

29. Yoshimatsu T, Mihelakakis A, Han K. Early development of laboratory-reared silver sea bream, Sparus sarba. The Yellow Sea. (2002) 8 (1): 1- 8.

30. Songs YB, OH SR, Seo JP, Ji BG, Lim BS, Lee YD, Kim HB. Larval development and rearing of Longtooth Grouper, Epinephelus bruneus in Jeju Island, Korea. J. World Aquacult. Soc. (2005) 36 (2): 209 - 216.

31. Cunha M E, Ré P, Quental-Ferreira H, Gavaia PJ, Pousão-Ferreira P. Larval and juvenile development of dusky grouper Epinephelus marginatus reared in mesocosm. J. Fish Biol. (2013) 83: 448-465.

32. Yu HJ, Im YJ, Jo HS, Lee SJ, Kim J-K. Morphological development of eggs, larvae, and juvenile of Sebastes koreanus (Scorpaeniformes: Scorpaenidae) from the Yellow Sea. Ichthyol. Res. (2015) 62: 439-449.

33. Tung IH. On the egg development and larval stages of the grey mullet (Mugil cephalus Linnaeus). Rep. Inst. Fish. Biol. Minist. Econ.Aff. Nat. Taiwan Univ. (1973) 3: 187-215.

34. Fukuhara O. Morphological and functional development of larval and juvenile Limanda yokohamae (Pisces: Pleuronectidae) reared in the laboratory. Marine Biology (1988) 99: 271-281.

35. Fukuhara O, Fushimi T. Fin differentiation and squamation of artificially reared grouper, Epinephelus akaara. Aquaculture (1988) 69: 379-386.

36. Pinto PIS, Estêvão MD, Redruello B, Socorro SM, Canário AVM, Power DM. Immunohistochemical detection of estrogen receptors in fish scales. Gen. Comp.Endocrinol. (2009) 160: 19-29. 
الملخص العربى

\section{دراسة مورفولوجية تطور اليرقات والانتقال إلى مرحلة الصغار فى أسماك الطوبار}

مصطقى عبد الوهاب موسى' ـ نهى عبد الحميد خليل ا ـ نوال مصطفى الجوهرى؟

' معمل تناسل وتفريخ الأسماكك ـ المعهد القومى لعلوم البحار والمصايد

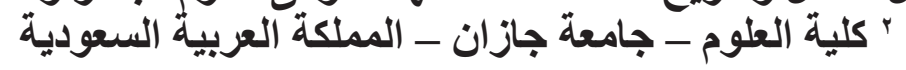

المقدمة: الوصف التفصيلي لمر احل تطور اليرقات والصغار في أسماك الطوبار غير موجود حتى الآن. الهذف من البحث: يهدف هذا البحث إلى وصف تطور اليرقات والانتقال إلى مرحلة الصغار في أسماك الطوبار بعد التفريخ المُحفز . المادة والطرق: فى هذه الدر اسة تم وصف التطور لأسماك الطوبار خلال فترة التربية المبكرة التي استمرت 63 يومًا بعد الفقس. النتائج: أوضحت النتائج أن اليرقات حديثة الفقس كانت ذات فم وفتحة شرج مغلقة. بعد سبعة أيام من الفقس، “فتح الفم و اختفى كل من الكيس المحي و الكريات الزيتية. عند اليوم الرابع عشر، يكون لليرقات زعانف مميزة ويزداد تصبغ بن الجلا. في 21 يومًا بعد الفقس، يكون لليرقات تلون متغير مع كثافة أكبر . بعد 28 يومًا من الفقس، ز اد عمق جسم اليرقات وتحتوي المعدة على بعض الطعام مما يدل على قدرة اليرقات على هضم الطعام الخارجي. فى اليرقات ذات عمر 35 يومًا تصبح العيون مصطبغة بالكامل. عند 42 يومًا بعد الفقس، يكون لليرقات كثافة عالية من التصبغ في جميع أنحاء الجسم وزعنفة ذيلية شفافة بأشعة. 49 يومًا بعد الفقس، يكون جسم صغار الأسماك مددودًا بوضوح ومضغوطًا جانبيًا

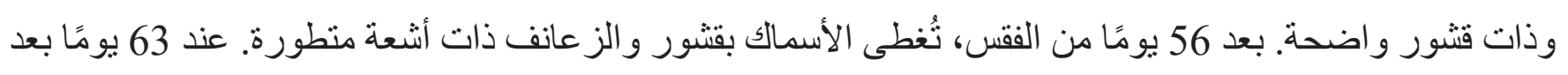
الفقس، يصبح الجسم كبيرًا و مغطى بالكامل بقشور وكثافة عالية من التصبغ. تبدأ اليرقات في التحول إلى مرحلة الصغار بعد 42 يومًا من الفقس ثم تنتهي من التحول في 63 يومًا بعد الفقس. الأهم من ذللك، أن مرحلة صغار أسماك الطوبار يمكن التعامل معها بأمان في 63 يومًا بعد الفقس. الخلاصة: يتطلب إنتاج صغار أسماك الطوبار فترة 63 يومًا لإنتاج الإصبعيات. 